\title{
Relative performance of various integrated farming system models with respect to system productivity, economics and employment generation
}

\author{
S.N. VINODAKUMAR*, B.K. DESAI, A.S. CHANNABASAVANNA, SATYANARAYANA RAO, \\ M.G. PATIL ${ }^{1}$ AND S. S. PATIL ${ }^{2}$ \\ Department of Agronomy, University of Agricultural Sciences, RAICHUR (KARNATAKA) INDIA
}

\begin{abstract}
A field experiment was conducted at Main Agricultural Research Station, Raichur (Karnataka) during 2012-13 and 201314 to evaluate the relative performance of different integrated farming system (IFS) models. Different combination of various crops, animals, fishes and poultry birds were examined in the form of seven integrated farming systems (IFS) models. The mean of two years indicated that, cotton based integrated farming system model $\mathrm{F}_{7}$ recorded higher system productivity $(10,903 \mathrm{~kg} / \mathrm{ha} /$ year) and net returns (Rs.1,89,069/ha/year), over conventional cotton alone $\left(F_{1}\right)$ system $(3,061 \mathrm{~kg} / \mathrm{ha} /$ year and Rs.74,592/ha/year, respectively). The productivity per day was 3.56 folds higher in $\mathrm{F}_{7}$ farming system model $(29.87 \mathrm{~kg} / \mathrm{ha} / \mathrm{day})$ over conventional system of cotton alone $(8.39 \mathrm{~kg} / \mathrm{ha} /$ day $)$. Among different models, $\mathrm{F}_{7}$ system recorded maximum total productivity in terms of cotton kapas equivalent yield, net returns and employment.
\end{abstract}

Key Words : Cotton kapas equivalent yield, Economics, Employment generation integrated farming system, System productivity

View Point Article : Vinodakumar, S. N., Desai, B.K., Channabasavanna, A.S., Rao, Satyanarayana, Patil, M.G. and Patil, S.S. (2017). Relative performance of various integrated farming system models with respect to system productivity, economics and employment generation. Internat. J. agric. Sci., 13 (2) : 348-352, DOI:10.15740/HAS/IJAS/13.2/348-352.

Article History : Received : 21.03.2017; Revised : 28.04.2017; Accepted : 12.05.2017

\footnotetext{
* Author for correspondence:

${ }^{1}$ Department of Horticulture, University of Agricultural Sciences, RAICHUR (KARNATAKA) INDIA

${ }^{2}$ Department of Agricultural Economics, University of Agricultural Sciences, RAICHUR (KARNATAKA) INDIA
} 